\title{
Steroid hormone receptors and direct effects of steroid hormones on ram spermatozoa
}

\author{
S Gimeno-Martos, M González-Arto, A Casao, M Gallego, J A Cebrián-Pérez, T Muiño-Blanco \\ and R Pérez-Pé \\ Department of Biochemistry and Molecular and Cell Biology - Environmental Sciences Institute of Aragón (IUCA), \\ Faculty of Veterinary Medicine, University of Zaragoza, Spain \\ Correspondence should be addressed to R Pérez-Pé; Email: rosperez@unizar.es
}

\begin{abstract}
This study was based on the assumption that steroid hormones present in the female genital tract may have a rapid effect on ram spermatozoa by interaction with specific surface receptors. We demonstrate the presence of progesterone (PR) and estrogen (ER) receptors in ram spermatozoa, their localization changes during in vitro capacitation and the actions of progesterone (P4) and $17 \beta$-estradiol (E2) on ram sperm functionality. Immunolocalization assays revealed the presence of PR mainly at the equatorial region of ram spermatozoa. Western blot analyses showed three bands in ram sperm protein extracts of 40-45 kDa, compatible with those reported for PR in the human sperm membrane, and both classical estrogen receptors (66 kDa, ER $\alpha$ and $55 \mathrm{kDa}, \mathrm{ER} \beta)$. ER $\alpha$ was located in the postacrosomal region of all the spermatozoa and ER $\beta$ on the apical region of $63.7 \%$ of the cells. The presence of ER $\beta$ was correlated with the percentage of non-capacitated spermatozoa evaluated by chlortetracycline staining $(R=0.848, P<0.001)$. This significantly decreased after in vitro capacitation and nearly disappeared when acrosome reaction was induced. The addition of $\mathrm{P} 4$ and $\mathrm{E} 2$ before in vitro capacitation resulted in a higher $(\boldsymbol{P}<\mathbf{0 . 0 0 1})$ acrosome-reacted sperm rate compared with the control $(\mathbf{1 3 . 0} \%)$, noticeably greater after $3 \mathrm{~h}$ and when added to a high-cAMP medium $(37.3 \%$ and $\mathbf{4 7 . 0} \%$ with E2 and P4, respectively). In conclusion, the results of this study demonstrate for the first time that ovine spermatozoa have progesterone and estrogen receptors and that both steroid hormones are related with the induction of the acrosome reaction.

Reproduction (2017) 154 469-481
\end{abstract}

\section{Introduction}

Steroid hormones, such as estrogens and progesterone, play a crucial role in the regulation of reproductive events in mammals. It is well established that these hormones regulate gene expression in the hypothalamichypophyseal gonadal axis through nuclear receptors (Beato et al. 1996). Apart from their genomic action, steroid hormones exert rapid effects on several types of cells by binding to receptors in the plasma membrane, generally affecting signal transduction responses (see review in Bishop \& Stormshak 2008).

Progesterone (P4) and 17- $\beta$ estradiol (E2) are present in the female genital tract. The concentrations of these hormones in the follicular fluid have been estimated in the nanomolar range (Carson et al. 1981), and part of this fluid is released into the oviduct together with the oocyte at the moment of ovulation. Furthermore, after ovulation, the cumulus cells surrounding the oocyte secrete $\mathrm{P} 4$ and E2 (Vanderhyden \& Tonary 1995, Chian et al. 1999), which could reach micromolar levels (Frederick et al. 1991) and diffuse to form a molecular gradient toward the edge of the cumulus matrix and beyond (Teves et al. 2006). Thus, it is very difficult to estimate the steroid hormone concentration to which the spermatozoa are exposed, even more so when considering other factors such as the moment of the oestrus cycle, the number of cells constituting the cumulus matrix, the proximity to the oocyte or differences between mammal species.

A large number of studies can be found in the literature concerning the non-genomic actions of $\mathrm{P} 4$ and E2 on spermatozoa, especially in humans (reviewed in Bishop \& Stormshak 2008 and Baldi et al. 2009). P4 may stimulate the hyperactivation (Uhler et al. 1992), chemotaxis (Jaiswal et al. 1999, Oren-Benaroya et al. 2008), in vitro capacitation (de Lamirande et al. 1998, Yamano et al. 2004) and the acrosome reaction in human spermatozoa (Osman et al. 1989, Kay et al. 1994). In other mammalian species, P4 has mainly been related with the induction of the acrosome reaction in mouse (Roldan et al. 1994), pig (Melendrez et al. 1994), goat (Somanath et al. 2000) and stallion (Meyers et al. 1995), and with chemotaxis in rabbit (Guidobaldi etal. 2008). On the other hand, the findings relating to the effects of E2 on spermatozoa are contradictory. While for some authors the main role of this hormone may be to modulate the progesterone effects on hyperactivation (Fujinoki 2010, 
Fujinoki et al. 2016), capacitation (Sebkova et al. 2012) or the acrosome reaction (Vigil et al. 2008), others suggest a direct stimulating effect on sperm functionality (Adeoya-Osiguwa et al. 2003, Ded et al. 2013). There are scarcely any studies about the non-genomic effects of steroid hormones on spermatozoa in ovine.

The way in which steroid hormones exert rapid nongenomic actions might either involve the nuclear steroid receptors acting on different cellular signalling or be mediated by membrane receptors, which could be either the classical receptors targeted to the plasma membrane or totally different ones (Luconi et al. 2004). In human spermatozoa, several studies have shown evidence of the presence of functionally active novel membrane receptors for progesterone (PR), excluding the existence of the classical nuclear receptors (Castilla et al. 1995, Luconi et al. 1998). However, the expression of the conventional isoforms PRA and PRB has also been reported (De Amicis et al. 2011), suggesting the presence of different types of PRs. Numerous authors have attributed the rapid effects of E2 on spermatozoa to its binding to the classical estrogen receptors (ER $\alpha$ and $E R \beta$ ) (Aquila et al. 2004), although the $G$ protein-coupled estrogen receptor (GPER) has recently been identified in humans (Rago et al. 2014). Likewise, putative steroid receptors mediating fast effects on sperm functionality have been described in other species such as dog, goat, pig or stallion (Cheng et al. 1998, Sirivaidyapong et al. 1999, Somanath et al. 2000, De Amicis et al. 2011, Arkoun et al. 2014), but there is no information concerning ovine spermatozoa.

Given the above information, we can hypothesize that steroid receptors may mediate the fast effects of steroid hormones in ram spermatozoa. To prove this hypothesis, the specific aims of this study were (1) to evidence the presence of progesterone and estrogen receptors in ram spermatozoa; (2) to determine whether in vitro capacitation has any effects on their localization and (3) to study the effects of both steroid hormones on ram sperm functionality.

\section{Material and methods}

Unless otherwise stated, all reagents were purchased from Sigma-Aldrich.

\section{Semen collection and processing}

Semen was collected from nine 2- to 5 year-old Rasa Aragonesa rams using an artificial vagina. The rams, which belonged to the National Association of Rasa Aragonesa Breeding (ANGRA), were kept at the Experimental Farm of the Veterinary School of the University of Zaragoza under uniform nutritional conditions, with an abstinence period of two days. Second ejaculates were pooled and used for each assay, to avoid individual differences (Ollero et al. 1996).
All experimental procedures were performed under Project License PI34/11 approved by the Ethics Committee for Animal Experiments of the University of Zaragoza.

A seminal plasma-free sperm population was obtained using a dextran swim-up procedure as described previously (GarciaLopez et al. 1996) performed in a medium with the following composition: $200 \mathrm{mM}$ sucrose, $50 \mathrm{mM} \mathrm{NaCl}, 18.6 \mathrm{mM}$ sodium lactate, $21 \mathrm{mM}$ HEPES, $10 \mathrm{mM} \mathrm{KCl}, 2.8 \mathrm{mM}$ glucose, $0.4 \mathrm{mM}$ $\mathrm{MgSO}_{4}, 0.3 \mathrm{mM}$ sodium pyruvate, $0.3 \mathrm{mM} \mathrm{K}{ }_{2} \mathrm{HPO}_{4}, 5 \mathrm{mg} / \mathrm{mL}$ bovine serum albumin (BSA), $30 \mathrm{mg} / \mathrm{mL}$ dextran, $1.5 \mathrm{IU} / \mathrm{mL}$ penicillin and $1.5 \mathrm{mg} / \mathrm{mL}$ streptomycin $(\mathrm{pH} 6.5)$.

\section{In vitro capacitation and acrosome reaction induction}

For the induction of in vitro capacitation, aliquots of swimup-selected spermatozoa $\left(1.6 \times 10^{8} \mathrm{cells} / \mathrm{mL}\right)$ were incubated for $3 \mathrm{~h}$ at $39^{\circ} \mathrm{C}$ in a humidified incubator with $5 \% \mathrm{CO}_{2}$ in air. Incubations were performed in a TALP medium (Parrish et al. 1988) composed of $100 \mathrm{mM} \mathrm{NaCl}, 3.1 \mathrm{mM} \mathrm{KCl}, 25 \mathrm{mM}$ $\mathrm{NaHCO}_{3}, 0.3 \mathrm{mM} \mathrm{NaH}_{2} \mathrm{PO}_{4}, 21.6 \mathrm{mM} \mathrm{Na}$ lactate, $3 \mathrm{mM} \mathrm{CaCl}$, $0.4 \mathrm{mM} \mathrm{MgCl}, 10 \mathrm{mM}$ HEPES, $1 \mathrm{mM} \mathrm{Na}$ pyruvate, $5 \mathrm{mM}$ glucose and $5 \mathrm{mg} / \mathrm{mL}$ BSA ( $\mathrm{pH} 7.3$ adjusted with $\mathrm{NaOH}$ ) or in a high-cAMP medium (cocktail, cAMP-PKA pathway), already successfully demonstrated for capacitating ram spermatozoa (Grasa et al. 2006 Colas et al. 2008), composed of dibutyrylcAMP (db-cAMP, Sigma Chemical Co.; $1 \mathrm{mM}$ ), caffeine and theophylline (both inhibitors of phosphodiesterases, Sigma Chemical Co.; $1 \mathrm{mM}$ each), okadaic acid (OA, a broad spectrum phosphatase inhibitor, Sigma Chemical Co.; $0.2 \mu \mathrm{m}$ ) and methyl- $\beta$-cyclodextrin (M- $\beta$-CD, Sigma Chemical Co.; $2.5 \mathrm{mM})$.

The acrosome reaction was induced by the addition of lysophosphatidylcholine (LPC) to the high-cAMPcapacitated samples (Parrish et al. 1988). To this end, $5 \mu \mathrm{L}$ LPC $(300 \mu \mathrm{g} / \mathrm{mL})$ was added to $95 \mu \mathrm{L}$ capacitated samples and incubated at $39^{\circ} \mathrm{C}, 5 \% \mathrm{CO}_{2}$ and $100 \%$ humidity for $20 \mathrm{~min}$ (Gomez et al. 1997).

Control samples without the addition of the cocktail or LPC were maintained under the same conditions in both the treatments: in vitro capacitation and acrosome reaction.

In order to evaluate the effects of 17- $\beta$ estradiol (E2) and progesterone (P4) on sperm functionality, hormones were added to aliquots of swim-up-selected spermatozoa $\left(1.6 \times 10^{8}\right.$ cells $\left./ \mathrm{mL}\right)$ diluted in a TALP or a high-cAMP (cocktail) medium. Both hormones were diluted separately in DMSO and PBS and added to the sperm samples to yield final concentrations of $1 \mu \mathrm{M}, 10 \mathrm{nM}$ or $100 \mathrm{pM}$ of each. The final concentration of DMSO in all the samples was $0.1 \%$. A control group containing the same DMSO concentration was included.

\section{Sperm motility analysis}

Motility kinematic parameters underwent computer-assisted measurement using a CASA system (ISAS 1.0.4; Proiser $\mathrm{SL}$, Valencia, Spain) with a video camera (Basler A312f, Basler Vision Components, Exton, PA, USA) mounted on a microscope (Nikon eclipse 50i, Nikon) equipped with a $10 x$ 
negative-phase contrast lens and a $10 \times$ projection ocular. Samples $(6 \mu \mathrm{L})$ were placed between pre-warmed slides and cover slips and maintained at $37^{\circ} \mathrm{C}$ during analysis by a heated slide holder. From a single field, 25 consecutive digitalized images were analysed. The percentages of total motile (TM) and progressive motile (PM) spermatozoa were evaluated. The kinematic parameters recorded for each spermatozoon were curvilinear velocity $(\mathrm{VCL}, \mu \mathrm{m} / \mathrm{s}$ : the average path velocity of the sperm head along its actual trajectory); straight line velocity (VSL, $\mu \mathrm{m} / \mathrm{s}$ : the average path velocity of the sperm head along a straight line from its first to its last position); average path velocity (VAP, $\mu \mathrm{m} / \mathrm{s}$ : the average velocity of the sperm head along its average trajectory); percentage of linearity (LIN, \%: the ratio between VSL and VCL); percentage of straightness (STR, \%: the ratio between VSL and VAP); wobble coefficient (WOB, \%: the ratio between VAP and VCL); mean amplitude of lateral head displacement $(\mathrm{ALH}, \mu \mathrm{m}$ : the average value of the extreme side-to-side movement of the sperm head in each beat cycle) and beat cross-frequency (BCF, Hz: the frequency with which the actual sperm trajectory crosses the average path trajectory).

\section{Sperm viability}

Two microlitres of carboxyfluorescein diacetate (CFDA, $1 \mathrm{mM}$ ) and propidium iodide (PI, $0.75 \mathrm{mM}$ ) were added to $200 \mu \mathrm{L}$ of sperm samples $\left(6 \times 10^{6} \mathrm{cell} / \mathrm{s} / \mathrm{mL}\right)$ based on a modification of the procedure described by Harrison and Vickers (Harrison \& Vickers 1990). Samples were incubated at RT in darkness for $15 \mathrm{~min}$ and analysed by flow cytometry. Measurements were performed on a Beckman Coulter FC 500 (Beckman Coulter Inc., Brea, CA, USA) with CXP software, equipped with two lasers of excitation (Argon ion laser $488 \mathrm{~nm}$ and solid state laser $633 \mathrm{~nm}$ ) and 5 filters of absorbance (FL1-525, FL2-575, FL3-610, FL4-675 and FL5-755, $\pm 5 \mathrm{~nm}$ each band pass filter). A minimum of 20,000 events was counted in all the experiments. The sperm population was gated for further analysis on the basis of its specific forward (FS) and side scatter (SS) properties; other non-sperm events were excluded. A flow rate stabilized at 200-300 cells/s was used. The argon laser and filters of 525 and $675 \mathrm{~nm}$ were used to avoid overlapping. The monitored parameters were FL1 (CFDA) and FL4 (PI).

\section{Assessment of capacitation status by CTC staining}

CTC is a fluorescent antibiotic that binds to membrane proteins of sperm cells. The fluorescence of bound CTC is enhanced by intracellular calcium, and the capacitation-induced changes in the labelling patterns showed by Ward and Storey (Ward \& Storey 1984) are widely considered to reflect the sperm capacitation state, although the molecular basis of CTC staining to sperm cells is not still understood. A CTC solution $(750 \mu \mathrm{M})$ was prepared daily in a buffer containing $20 \mathrm{mM}$ Tris, $130 \mathrm{mM} \mathrm{NaCl}$ and $5 \mu \mathrm{M}$ cysteine $(\mathrm{pH} 7.8)$ and passed through a $0.22-\mu \mathrm{m}$ filter (Merck Millipore). Thereafter, $20 \mu \mathrm{L}$ CTC solution and $5 \mu \mathrm{L}$ of $12.2 \%(\mathrm{w} / \mathrm{v})$ paraformaldehyde in $0.5 \mathrm{M}$ Tris- $\mathrm{HCl}(\mathrm{pH} 7.8)$ were added to a $18 \mu \mathrm{L}$ sperm sample and incubated at $37^{\circ} \mathrm{C}$ in the dark for $10 \mathrm{~min}$. At room temperature, a 4- $\mu \mathrm{L}$ aliquot of the stained sample was placed on a glass slide and mixed with $2 \mu \mathrm{L}$ of $0.22 \mathrm{M}$ triethylenediamine (DABCO) in glycerol:PBS (9:1). Samples were covered with $24 \times 48 \mathrm{~mm}$ coverslips, sealed with colourless enamel and stored in the dark at $4{ }^{\circ} \mathrm{C}$. For the evaluation of CTC patterns, samples were examined using a Nikon Eclipse E-400 microscope (Kanagawa, Japan) under epifluorescence illumination using a V-2A filter. All samples were processed in duplicate and at least 150 spermatozoa were scored per slide. Three sperm types were identified (Gillan et al. 1997): (1) non-capacitated (NC), showing an even distribution of yellow fluorescence over the head, with or without a bright equatorial band; (2) capacitated (C), with fluorescence on the anterior portion of the head and (3) acrosome-reacted cells, showing no fluorescence on the head, with or without a bright equatorial band.

\section{Avidin-biotin peroxidase assays}

Aliquots of $4 \times 10^{6}$ spermatozoa were fixed with $3.7 \%$ formaldehyde $(v / v)$ in PBS $(137 \mathrm{mM} \mathrm{NaCl}, 2.7 \mathrm{mM} \mathrm{KCl}$, $8.1 \mathrm{mM} \mathrm{Na} \mathrm{HPO}_{4}$ and $1.76 \mathrm{KH}_{2} \mathrm{PO}_{4}, \mathrm{pH} 7.2$ ) for $20 \mathrm{~min}$ at room temperature. Then, the cells were then centrifuged at $900 \times \mathrm{g}$ for $5 \mathrm{~min}$ and the pellet was resuspended in PBS. After fixation, $40 \mu \mathrm{L}$ of cell suspension was smeared onto poly-Llysine-coated slides and maintained at room temperature for $3 \mathrm{~h}$ to ensure good adhesion onto the slide.

Slides were rehydrated in PBS, and endogenous peroxidase was inactivated with $1.70 \%$ hydrogen peroxide in $100 \%$ ethanol for $30 \mathrm{~min}$. The slides were then washed in PBS and incubated in horse serum as a blocking reagent (supplied by Vector, Los Angeles, CA, USA) for $45 \mathrm{~min}$, followed by incubation with the specific antibody at a 1:50 dilution overnight. The chosen antibody to detect the progesterone receptor was PR (C-19) (Santa Cruz Biotechnology; Cat\# sc-538, RRID:AB_632263), an affinity purified rabbit polyclonal antibody raised against a peptide mapping at the C-terminus of PR of human origin, but also recommended for detection of progesterone receptors (PRA and PRB) in additional species such as equine, canine, bovine, porcine and avian. Antibodies used for the detection of estradiol receptors were rabbit polyclonal antibodies against $E R \alpha$ and $E R \beta$, respectively (ER $\alpha$ Santa Cruz Biotechnology; Cat\# sc-7207, RRID:AB_640249, and ER $\beta$ Santa Cruz Biotechnology; Cat\# SC-8974, RRID:AB_2102246).

Subsequently, the slides were incubated with a biotinylated anti-rabbit antiserum for $40 \mathrm{~min}$. An avidin-biotin-peroxidase complex (from Vector) was then applied for $45 \mathrm{~min}$. The binding sites of the primary antibodies were visualized by diaminobenzidine (DAB) and hydrogen peroxide solution (20 mg DAB in $100 \mathrm{~mL}$ of $0.05 \mathrm{M}$ Tris- $\mathrm{HCl}$ buffer, $\mathrm{pH} 7.6$, containing $0.005 \% \mathrm{H}_{2} \mathrm{O}_{2}$ ) for $5 \mathrm{~min}$. Counter-staining with Carazzi's haematoxylin was followed by dehydration and mounting. As negative controls, all samples were incubated with normal serum instead of the primary antibody, with the remaining procedure being the same.

The cells were examined under a Nikon Eclipse E-400 microscope (Kanagawa, Japan) under bright field illumination at $1000 \times$ magnification. Microscopic images were captured and processed with Nikon image software. 


\section{Indirect immunofluorescence assays}

Slides prepared as described previously were washed three times with PBS, and non-specific binding sites were blocked with $5 \%$ BSA (w/v) in PBS for $4 \mathrm{~h}$ at room temperature in a humidity chamber. After three washes in PBS, spermatozoa were incubated overnight at $4{ }^{\circ} \mathrm{C}$ with the primary antibody (anti-ER $\alpha$ (RRID:AB_640249), anti-ER $\beta$ (RRID:AB_2102246) and anti-PR (RRID:AB_632263) rabbit polyclonal antibody, respectively; Santa Cruz Biotechnology), diluted 1:50 (v/v) in PBS containing 1\% BSA (w/v). After three washes in PBS, the cells were incubated with the secondary antibody (Alexa Fluor 488 chicken anti-rabbit; Thermo Fisher Scientific; Cat\# A-21441, RRID:AB_2535859), diluted 1:800 (v/v), for 1.5 h at room temperature in a humidity chamber. The slides were then washed three times with PBS before the addition of $5 \mu \mathrm{L}$ of $0.22 \mathrm{M}$ triethylenediamine (DABCO) in glycerol:PBS $(9: 1 \mathrm{v} / \mathrm{v})$ to enhance and preserve cell fluorescence. Finally, the preparations were covered with coverslips, sealed with colourless enamel and visualized using a Nikon Eclipse E-400 microscope under epifluorescent illumination. All samples were processed in duplicate and at least 150 spermatozoa were scored per slide.

\section{Western blotting}

For PR and ER detection, sperm proteins were extracted from raw semen by diluting samples in PBS $\left(10^{8} \mathrm{cell} / \mathrm{sL}\right)$ and centrifuging in a microfuge at $900 \times \mathrm{g}$ for $6 \mathrm{~min}$ at room temperature. The supernatant was discarded, and the pellet was resuspended with $100 \mu \mathrm{L}$ of extraction buffer $(125 \mathrm{mM}$ Tris- $\mathrm{HCl}$ (p 6.8), 2\% SDS, 10\% $\beta$-mercaptoethanol, 20\% glycerol and $0.02 \%$ bromophenol blue). For the detection of phosphorylated proteins on tyrosine residues, aliquots of $3.2 \times 10^{7}$ cells of TALP- or cocktail-incubated samples were directly suspended in $100 \mu \mathrm{L}$ of extraction buffer. In both cases, after incubation at $100^{\circ} \mathrm{C}$ in a sand bath for $5 \mathrm{~min}$, the samples were centrifuged again at $7500 \times \mathbf{g}$ for $5 \mathrm{~min}$ at $4{ }^{\circ} \mathrm{C}$. The supernatant was recovered and, after adding $10 \%$ of a protease inhibitor cocktail, was stored at $-20^{\circ} \mathrm{C}$.

For SDS-PAGE, $5 \times 10^{6}$ cells were loaded on $10 \%(\mathrm{w} / \mathrm{v})$ SDSPAGE gels, separated by standard SDS-PAGE and transferred onto a PVDF membrane using a transfer unit (Trans-Blot Turbo Transfer System, Bio-Rad). After the blocking of non-specific sites with $5 \%$ BSA in PBS for $4 \mathrm{~h}$, the proteins were detected by incubating overnight at $4{ }^{\circ} \mathrm{C}$ with a primary antibody diluted 1:1000 in 0.1 Tween20 PBS containing 1\% BSA. For the detection of steroid hormone receptors, the above-mentioned anti-ER $\alpha,-E R \beta$ and $-P R$ rabbit polyclonal antibodies were used. After extensive washing, the membranes were incubated for $1 \mathrm{~h}$ and $15 \mathrm{~min}$ at room temperature with a secondary donkey anti-rabbit antibody (Donkey Anti-Rabbit IgG, IRDye 800CW Conjugated antibody; LI-COR Biosciences, Lincoln, NE, USA; Cat\# 926-32213, RRID:AB_621848 Li-COR Biosciences,) diluted in 0.1 Tween20 PBS containing 1\% BSA (dilution 1: 35000 and 1:15000 for PR and ER, respectively). As positive controls, we used the commercial cell lysates specifically recommended and supplied by the antibody manufacturer (Santa Cruz Biotechnology). MCF7 wholecell lysate, specifically recommended as the positive control for PR and ER $\alpha$, is derived from the MCF7 cell line (human breast adenocarcinoma). F9 whole-cell lysate, specifically recommended as the positive control for $E R \beta$, is derived from the F9 cell line (mouse testicular teratoma). Liver protein extract was also used as positive controls for all the abovementioned antibodies, on the basis of several studies reporting the presence of PR and ER in hepatic tissue (Xu et al. 2004, Varas \& Jahn 2005, Dressing et al. 2011). Liver protein extracts were obtained from ovine liver following the same protocol as sperm protein extracts. We carried out the Western blotting protocol using the corresponding antibody in each case.

For the detection of phosphorylated proteins on tyrosine residues, the procedure was the same as described above but using a mouse monoclonal anti-phosphotyrosine antibody (Monoclonal Antibody, clone 4G10; Millipore; Cat\# 05-321, RRID:AB_309678) as a primary antibody (dilution 1:1000) and a Donkey Anti-Mouse IgG, IRDye 800CW Conjugated antibody (LI-COR Biosciences; Cat\# 926-32212, RRID:AB_621847) as a secondary antibody (dilution 1:15000). Anti-actin antibody (Sigma-Aldrich; Cat\# A2066, RRID:AB_476693) produced in rabbit was used as a loading control (1:500 in 0.1 Tween20 PBS containing $1 \% \mathrm{BSA}$ ), followed by incubation with a secondary Donkey Anti-Rabbit IgG, IRDye 680RD Conjugated antibody (LI-COR Biosciences; Cat\# 926-32223, RRID:AB_621845) diluted $1: 15000$.

Finally, the membranes were scanned after washing using the Odyssey Clx Infrared Imaging System (Li-COR Biosciences). To prove that the signal was specific, Western blotting omitting either primary or secondary antibodies was performed (data not shown).

Western blot images were quantified using Odyssey $\mathrm{Clx}$ Infrared Imaging System software (Li-COR Biosciences) to determine the relative intensity of the tyrosine phosphorylated protein bands. The total intensity signal of each lane was evaluated as the sum of the peak intensity of all bands in the lane and normalized to the actin loading control.

\section{Statistical analysis}

Differences between groups in motility, viability, CTC staining and receptor distribution were analysed by means of the chisquare test. Differences in protein tyrosine phosphorylation levels were analysed by ANOVA followed by the Bonferroni post hoc test after evaluation of the data distribution by the Kolmogorov-Smirnov test. The correlation between the capacitation state and ER $\beta$ immunolocalization of the spermatozoa was analysed by Pearson's correlation test, after evaluation of the data distribution by the Kolmogorov-Smirnov test. All statistical analyses were performed using SPSS, version 14.0 (SPSS).

\section{Results} Identification and immunolocalization of progesterone
and estrogen receptors in ram spermatozoa

The avidin-biotin peroxidase complex assays revealed that progesterone receptors (PR) were located at the equatorial region of all the spermatozoa and also 

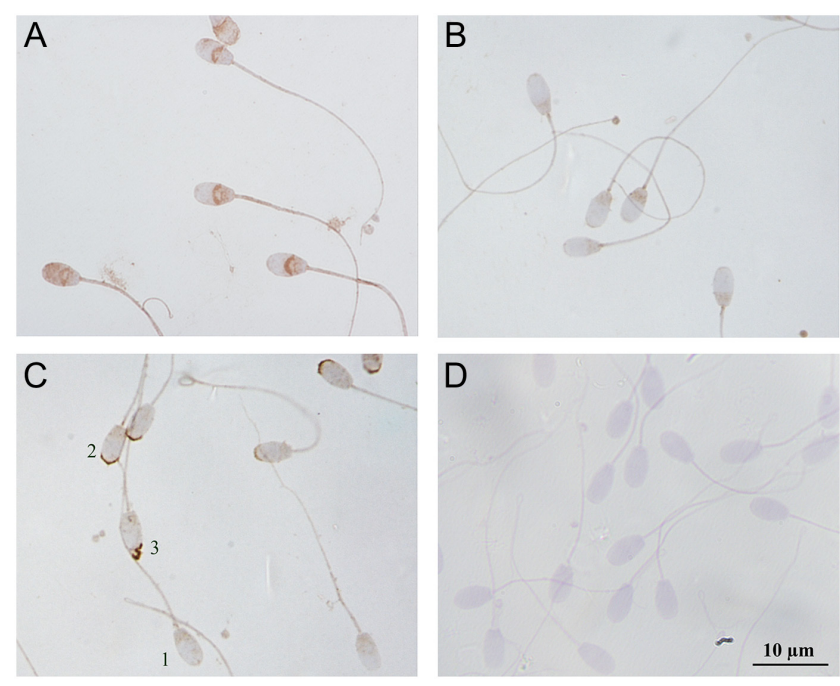

Figure 1 Immunocytochemical localization of progesterone receptor (A), estrogen receptor $\alpha(B)$ and $\beta(C)$ in ram spermatozoa.

Magnification 1000x. Negative controls are shown (D).

appeared faintly on the midpiece of the tail (Fig. 1A). Both estrogen receptors, $E R \alpha$ and $E R \beta$, are also present in ram spermatozoa. The immunocytochemistry assays revealed that ER $\alpha$ was located at the postacrosomal region of all the cells although the labelling was always weaker than those with the other antibodies used (Fig. 1B). Two sperm subpopulations regarding $E R \beta$ signalling were found: one showing no antibody labelling (ER $\beta$-, sperm 1 in Fig. 1C) and another showing intense reactivity on the apical region of the acrosome $(E R \beta+, 63.7 \pm 4.6 \%$, sperm 2 in Fig. 1C). Curiously, some of the ER $\beta$ + cells appeared to be losing the stained region (sperm 3 in Fig. 1C). In all the assays, the omission of the primary antibody resulted in no staining, which rules out the possibility of non-specific binding of the secondary antibodies (Fig. 1D).

Western blot analyses for PR in ram sperm protein extracts identified three protein bands corresponding to a molecular weight ranging between 40 and $45 \mathrm{kDa}$.
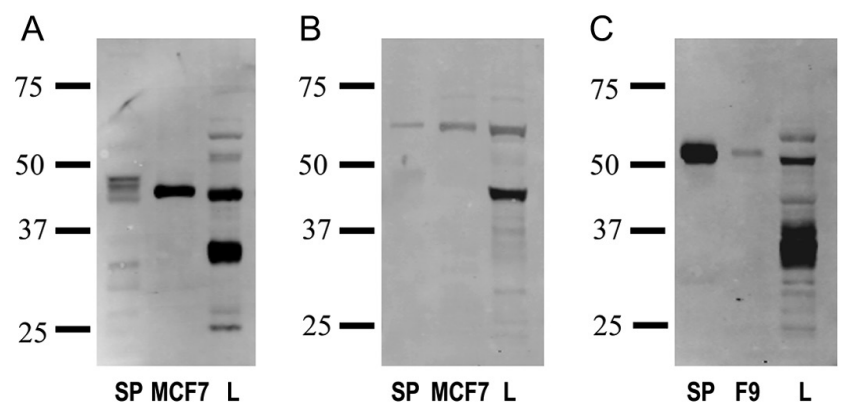

Figure 2 Western blot analysis of the presence of progesterone receptor (A), estrogen receptor $\alpha(B)$ and $\beta(C)$ in ram sperm protein extracts (SP, lane 1 in $A, B$ and $C$ ). Positive controls: MCF7 cell extracts (MCF7, lane 2, A and B), F9 cell extracts (F9, lane 2, C) and ovine liver protein extracts (L, lane 3, A, B and C).
The molecular weights of these bands coincide with those found in the positive controls (Fig. 2A), but not with the expected values for either the classical or the nuclear PR described by the commercial supplier of the antibody $(81 \mathrm{kDa}$ and $116 \mathrm{kDa}$ for PRA and $\mathrm{PRB}$, respectively). Regarding estrogen receptors (ER), Western blot analyses revealed a band of approximately $65 \mathrm{kDa}$ for ER $\alpha$ (SP, lane 1 of Fig. 2B) and another of $55 \mathrm{kDa}$ for ER $\beta$ (SP, lane 1 of Fig. 2C), which correspond to the molecular weight of the amino acid sequence recognized by these antibodies ( 66 and $56 \mathrm{kDa}$ for ER $\alpha$ and ER $\beta$ respectively), according to the manufacturer. The bands observed were also found in the positive control recommended by the manufacturer (MCF7 and F9 cell lysates for $E R \alpha$ and $E R \beta$, respectively, lane 2 of Fig. $2 \mathrm{~B}$ and $\mathrm{C}$ respectively) and in the ovine liver protein extracts ( $\mathrm{L}$, lane 3 of Fig. $2 \mathrm{~B}$ and $\mathrm{C}$, respectively).

\section{Changes in the immunolocalization of progesterone and estrogen receptors according to the sperm capacitation state}

In order to evaluate a possible variation in the localization of steroid hormone receptors associated to sperm capacitation, we investigated the presence and cellular distribution of PR, ER $\alpha$ and ER $\beta$ in control, capacitated and acrosome-reacted samples by indirect immunofluorescence. As expected, the assessment of the capacitation state by CTC staining revealed a significant increase $(P<0.05)$ in the capacitated $(C)$ and acrosome-reacted (AR) sperm patterns after the induction of both in vitro capacitation with the cocktail (high-CAMP concentration) and the acrosome reaction with LPC, compared with the control group (Table 1). However, no change was observed in PR and ER $\alpha$ localization after both processes (data not shown). In contrast, significant differences in the percentage of spermatozoa showing $E R \beta$ labelling (ER $\beta+$ cells) were evidenced (Table 1). The high $E R \beta+$ sperm rate in control samples $(65.2 \pm 3.7 \%)$ significantly decreased after incubation with either the cocktail $(24.6 \pm 1.2 \%$; $P<0.05)$ or LPC $(6.3 \pm 1.6 \% ; P<0.05)$. On the basis of these results, we investigated whether there was any correlation between the ER $\beta$ labelling and the different capacitation patterns determined by the CTC staining (Fig. 3). Statistical analysis showed a highly significant positive correlation between the presence of ER $\beta$ and the NC sperm rate $(r=0.848, P<0.001$; Fig. 4$)$ and a highly negative correlation with both the $C(r=-0.524$, $P<0.01)$ and $\mathrm{AR}(\mathrm{r}=-0.811, P<0.001)$ sperm rate.

\section{Effects of different concentrations of progesterone (P4) and 17 -estradiol (E2) on sperm functionality}

Once the presence of progesterone and ERs in ram spermatozoa was demonstrated, we assessed the effects of steroid hormones on several sperm functionality 
Table 1 Effect of in vitro induction of capacitation and acrosome reaction on the estrogen receptor $\beta$ labelling in ram spermatozoa.

\begin{tabular}{lcccc}
\hline & & \multicolumn{3}{c}{ Chlortetracycline (CTC) staining patterns } \\
\cline { 3 - 5 } \multicolumn{1}{c}{ Sperm sample } & ER $\beta+$ cells $(\%)$ & NC $(\%)$ & C $(\%)$ & R $(\%)$ \\
\hline Control & $65.2 \pm 3.7^{\mathrm{a}}$ & $72.1 \pm 1.3^{\mathrm{a}}$ & $18.4 \pm 1.5^{\mathrm{a}}$ & $9.2 \pm 1.0^{\mathrm{a}}$ \\
In vitro capacitated & $24.6 \pm 1.2^{\mathrm{b}}$ & $51.5 \pm 3.2^{\mathrm{b}}$ & $30.9 \pm 3.1^{\mathrm{b}}$ & $18.1 \pm 0.7^{\mathrm{b}}$ \\
AR & $6.3 \pm 1.6^{\mathrm{c}}$ & $26.7 \pm 1.8^{\mathrm{c}}$ & $27.9 \pm 0.9^{\mathrm{b}}$ & $45.4 \pm 1.3^{\mathrm{c}}$ \\
\hline
\end{tabular}

Percentage of spermatozoa with estrogen receptor $\beta$ labelling (ER $\beta+$ ) assessed by indirect immunofluorescence (IIF), and capacitation status (NC: non-capacitated; C: capacitated; R: acrosome reacted) assessed by chlortetracycline (CTC) staining, in control, in vitro capacitated and acrosome reacted samples. Results are shown as mean \pm S.E.M., $n=10$. Different letters $(\mathrm{a}, \mathrm{b}, \mathrm{c})$ mean statistical differences of $P<0.05$.

markers. After $3 \mathrm{~h}$ of incubation in capacitating conditions in high-cAMP (cocktail) medium, a significant decrease in viability (sperm membrane integrity), motility (total and progressive) and velocity (VCL, VSL and VAP) was found $(P<0.001$, compared to control at $0 \mathrm{~h})$. P4 and E2 at $100 \mathrm{pM}$ induced a deeper decrease in TM sperm $(65.2 \pm 4.5 \%, 68.2 \pm 2.3 \%$ vs $75.0 \pm 2.1 \%$ for cocktail samples with $100 \mathrm{pM}$ P4 and E2, and without hormones, respectively). Progressive motility, kinematic parameters and sperm viability were not affected by the presence of hormones in incubation media (Table 2).

Regarding the capacitation status (CTC staining), no change was found after $1 \mathrm{~h}$ of incubation with both hormones in TALP-incubated samples (Fig. 5A). However, after $3 \mathrm{~h}$ of incubation, the effect of both hormones was significant, leading to a decrease in the $\mathrm{NC}$ sperm rate with both low and high concentrations of E2 and P4, concomitant with a higher percentage of AR spermatozoa compared with the control samples with no hormone $(25.5 \pm 8.3 \%$ and $28.3 \pm 9.8 \%$ for $100 \mathrm{pM}$ of both hormones vs $13.0 \pm 6.4 \%$ in control samples, $P<0.001$ ) (Fig. 5A). Furthermore, $1 \mu \mathrm{M}$ of E2 led to a significant increment in the capacitated sperm rate $(P<0.01)$. However, incubation with $10 \mathrm{nM}$ of both hormones did not significantly affect the physiological sperm status (Fig. 5A). Despite the considerable differences observed in CTC staining, statistical analysis of the densitometric evaluation of the protein tyrosine phosphorylation did not reveal any significant change (Fig. 5C and E).
When steroid hormones were added to the cocktailincubated samples, differences in the percentages of different CTC staining subtypes could already be detected after the first hour of incubation (Fig. 5B). As expected, the addition of a cocktail that maintains high intracellular cAMP levels led to a highly significant increment in the percentage of capacitated sperm relative to the control (TALP-incubated sample) $(53.8 \pm 6.2 \%$ vs $30.5 \pm 6.2 \%, P<0.001)$. Inclusion of P4 in the cocktail medium did not significantly modify this percentage relative to cocktail samples without the hormone, but gave rise to a significant increment in the percentage of AR spermatozoa (from $8.2 \pm 1.3 \%$ up to $23.5 \pm 4.7 \%$ with $1 \mu \mathrm{M} P 4, P<0.001)$. After $3 \mathrm{~h}$ of incubation, the proportion of capacitated cells was increased to $69.7 \pm 4.3 \%$ in cocktail samples without $\mathrm{P} 4$, while in the presence of this hormone between 41 and $45 \%$ of capacitated spermatozoa remained in all the samples, and this difference was highly significant $(P<0.001)$. Furthermore, the percentage of AR spermatozoa, which barely changed in cocktail samples without P4 $(13.0 \pm 2.0 \%)$, reached more than $40 \%$ in samples with the hormone (up to $47.0 \pm 3.7$ with $100 \mathrm{pM})$, this difference being highly significant in all cases $(P<0.001)$.

The inclusion of E2 in the cocktail medium did not account for any significant change in the proportion of capacitated cells after $1 \mathrm{~h}$ of incubation in capacitating conditions, similar to that observed in the presence of P4 (Fig. 5B). However, the percentage of AR cells was significantly increased to $23.5 \pm 9.0 \%$ with the highest
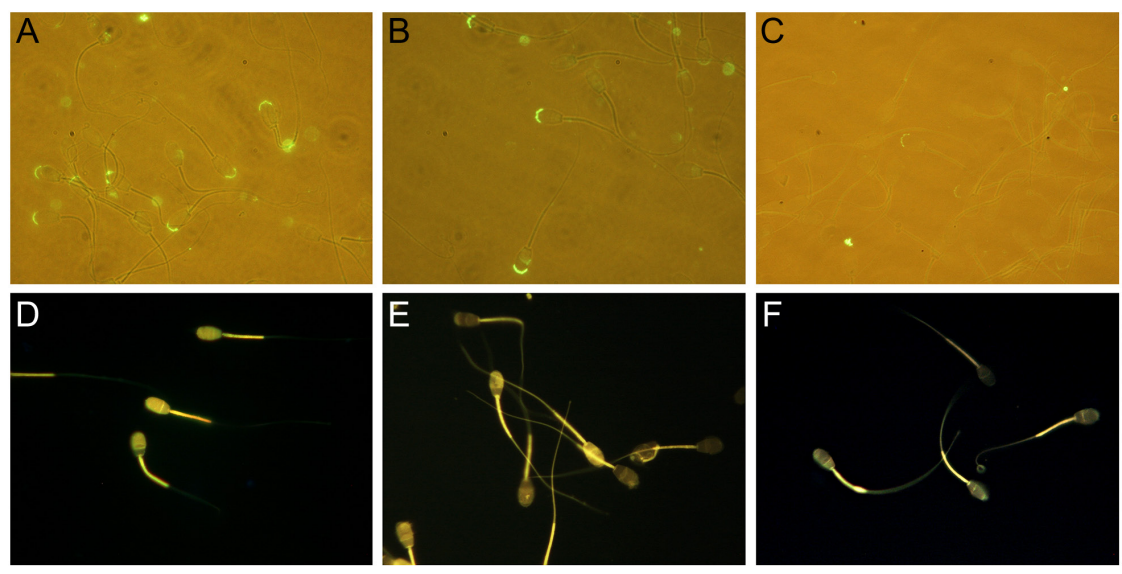

Figure 3 Representative images of immunocytochemical localization of ER $\beta$ (bright field and epifluorescence, A, B and C) and capacitation status assessed by chlortetracycline (CTC) staining (epifluorescence, D, E and F) in control ( $A$ and $\mathrm{D}$ ), in vitro capacitated (B and $\mathrm{E}$ ) and acrosome-reacted (C and F) ram spermatozoa (magnification 1000x). 


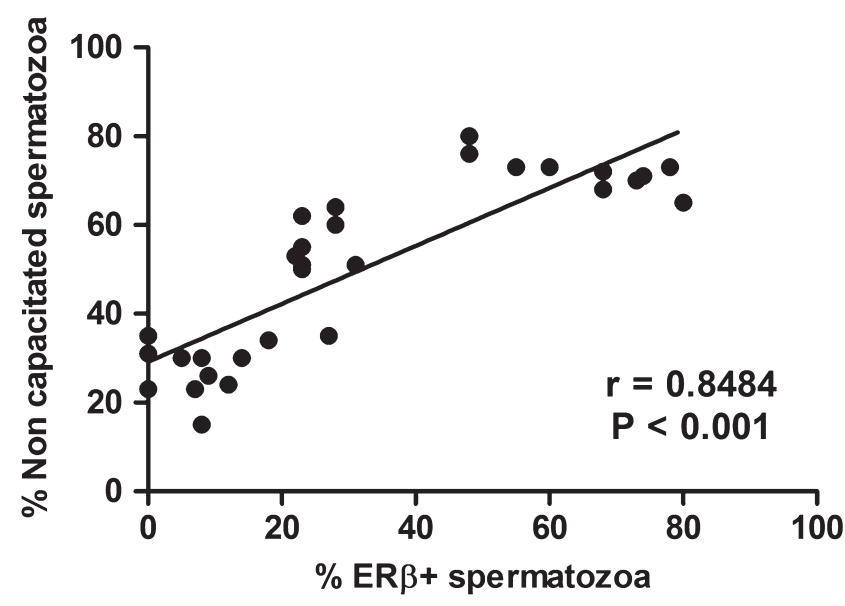

Figure 4 Graphic representation of the correlation found in ram spermatozoa between the presence of estrogen receptor $\beta(E R \beta+)$, localized by indirect immunofluorescence (IFF), and the noncapacitated sperm rate assessed by chlortetracycline (CTC) staining. Experiments were replicated 12 times with control, in vitro capacitated and acrosome-reacted sperm samples in each experiment $(n=36)$.

E2 concentration $(P<0.001)$. After $3 \mathrm{~h}$ of incubation, the proportion of capacitated cells increased in all the cocktail-containing samples. The addition of E2 accounted for a significant decrease in the capacitated sperm pattern from $69.7 \pm 4.3 \%$ in samples with no E2 to $45.7 \pm 3.18$ and $54.7 \pm 5.3 \%$ with $10 \mathrm{nM}$ and $1 \mu \mathrm{M}$ E2 respectively. In contrast, the percentage of AR cells was significantly higher in samples incubated with E2 (up to $37.3 \pm 8.6 \%$ with $10 \mathrm{nM} \mathrm{E} 2$ vs $13.0 \pm 2.0 \%$ in the control cocktail samples, $P<0.001)$. Densitometric evaluation of protein tyrosine phosphorylation showed an increase in the total band intensity in the cocktail samples in the presence of $\mathrm{P} 4$, which was significant with $100 \mathrm{pM}$ $(P<0.05)$ and $10 \mathrm{nM}(P<0.01)$ relative to the control at $3 \mathrm{~h}$, while the inclusion of E2 did not reveal any significant change (Fig. 5D and F).

\section{Discussion}

Progesterone and $17 \beta$-estradiol are present in the female genital tract, and several studies have shown their ability to exercise direct effects on spermatozoa (reviewed in Bishop \& Stormshak 2008 and Baldi et al. 2009) presumably by interaction with a specific receptor on the sperm surface (Luconi et al. 2004). In this study, we have revealed the presence of $P R$ at the equatorial region of ram spermatozoa, with also a faint signal at the midpiece. This localization is in concordance with that described in human spermatozoa (Sabeur et al. 1996), but not in other species such as pig and goat where PR has mainly been detected on the postacrosomal and apical regions (Somanath \& Gandhi 2002, De Amicis et al. 2012). Our results showed the presence of both ER on the head of ram spermatozoa, ER $\alpha$ at the postacrosomal part and ER $\beta$ at the apical region. Localization of both ERs partially coincides with that described in stallion (Arkoun et al. 2014), mouse (Sebkova et al. 2012) and human (Solakidi et al. 2005) spermatozoa, although other studies have shown a prevalent labelling at the flagellum of human and pig spermatozoa (Rago et al. 2007, Guido et al. 2011), where we did not detect any signalling at all. These differences could be due to either a specie-specific expression pattern or the use of different antibodies in the immunodetection assays. Additionally, differences between the localization of both ER suggest different roles in sperm physiology. Although ER $\alpha$ was evidenced at the postacrosomal region of all the spermatozoa, ER $\beta$ was found at the apical region of only about $63 \%$ of the cells, and some of them appeared to be losing their stained region. Therefore, we can hypothesize that this phenomenon may be attributed to an ER $\beta$ redistribution related to capacitation, and the data obtained support this idea. We found a strong significant correlation $(R=0.848, \quad P<0.001)$ between the presence of ER $\beta$ and the percentage of $\mathrm{NC}$ spermatozoa. Moreover, the percentage of labelled cells $(\mathrm{ER} \beta+)$ significantly decreased after in vitro capacitation, and nearly disappeared when the acrosome reaction was induced by LPC. All these data indicate that ER $\beta$ is involved in capacitation and the acrosome reaction of ram spermatozoa. In contrast, the expression and localization of $E R \alpha$ and PR did not change during capacitation or the acrosome reaction. Despite that we could assume that steroid hormone receptors described in the present study are associated to the plasma membrane as no permeabilisation was performed in the immunofluorescence assays, we cannot exclude the putative presence of intracellular receptors mediating rapids effects.

Classical nuclear receptors for progesterone, PR (A and $B$ ), are generated from an alternative splicing of the same gene (Conneely et al. 1989, Kastner et al. 1990) and have a molecular weight of 94 (PRA) and $120 \mathrm{kDa}$ (PRB) in human spermatozoa (De Amicis et al. 2011). In the present study, Western blot analyses for PR in ram sperm protein extracts identified three protein bands corresponding to a molecular weight between 40 and $45 \mathrm{kDa}$, which are different from those reported for $\mathrm{A}$ and $\mathrm{B}$ isoforms of the classical or nuclear $\mathrm{P} 4$ receptor of human spermatozoa, or those described by the commercial supplier of the antibody $(81 \mathrm{kDA}$ and $116 \mathrm{kDa}$ for PRA and PRB, respectively). A functionally active novel membrane PR has been reported in human spermatozoa, with two proteins bands of similar molecular masses (46-48 and 50-52 KDa, (Sabeur et al. 1996) or 54 and $57 \mathrm{kDa}$ (Luconi et al. 1998). Other putative sperm membrane PRs have also been described in dog (Cheng et al. 2005), goat (Somanath \& Gandhi 2002) or boar (Wu et al. 2006) spermatozoa. We can speculate that the proteins detected in the present study 


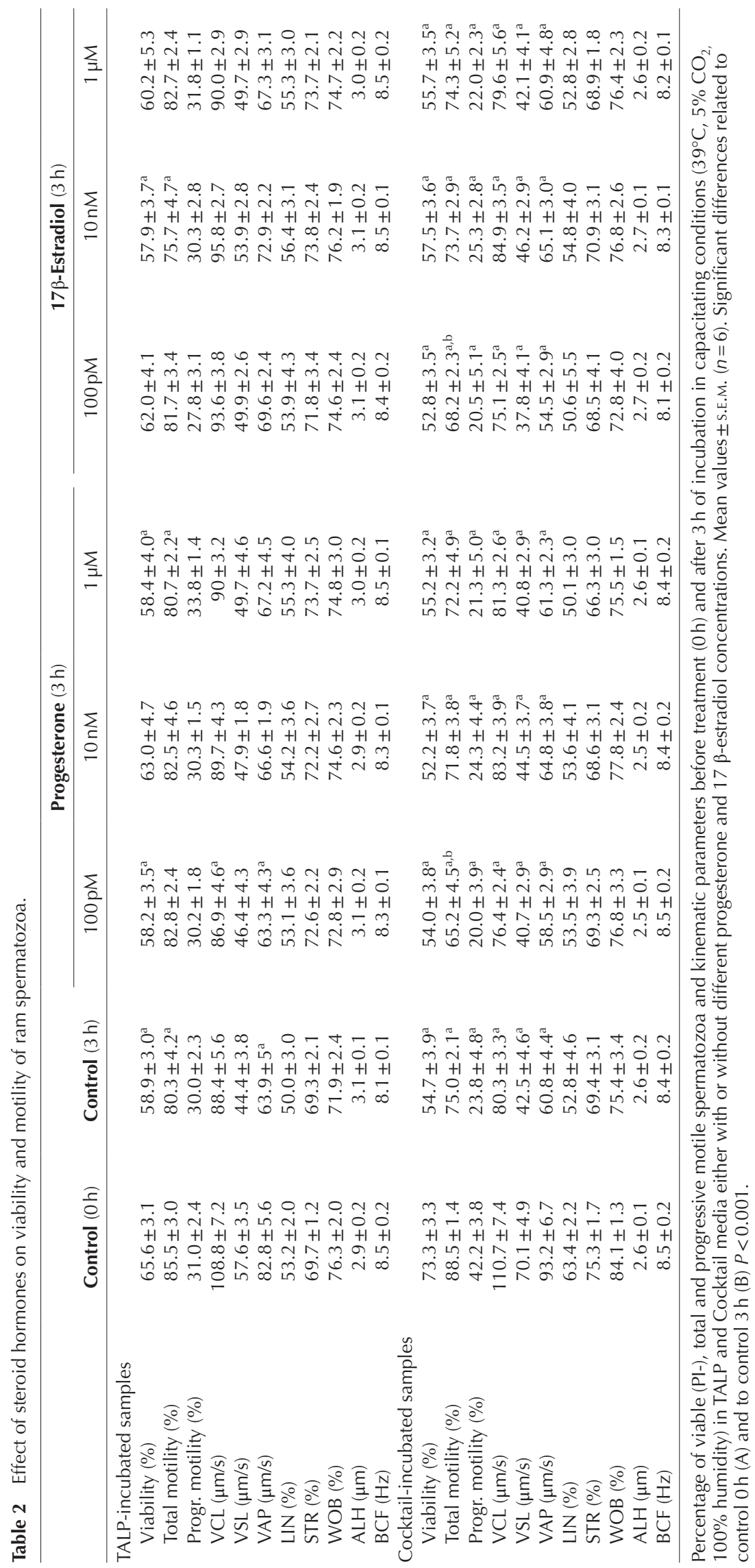


A

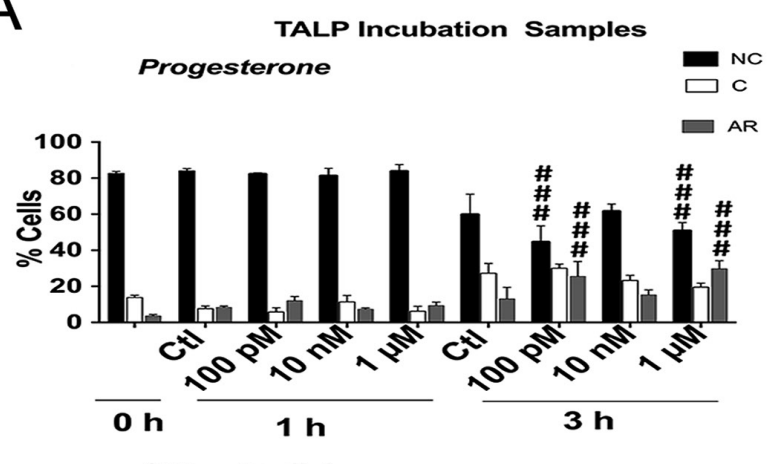

17- $\beta$ estradiol

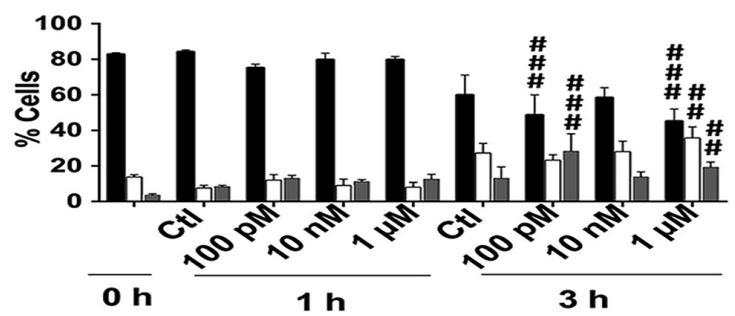

C

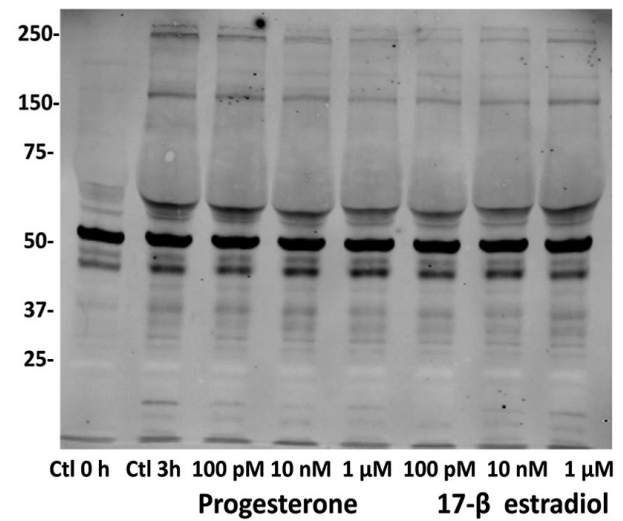

$E$

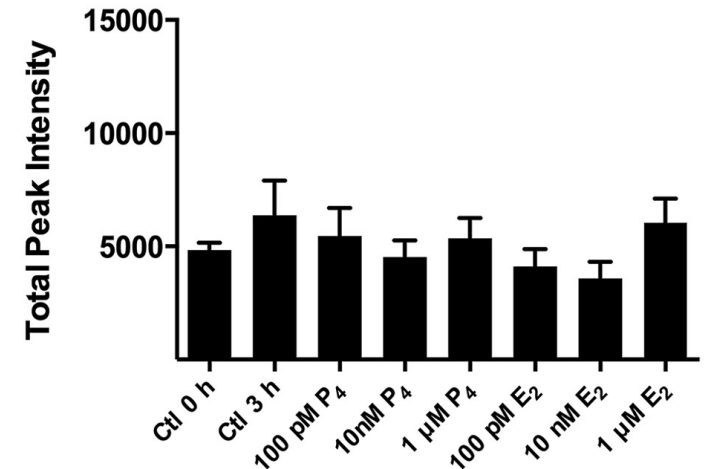

B
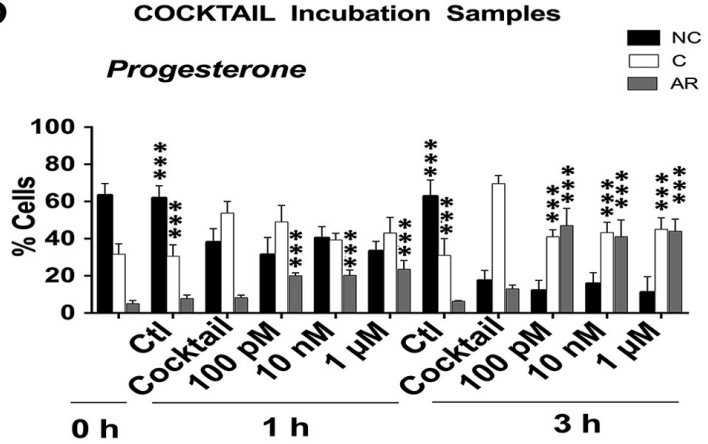

17- $\beta$ estradiol
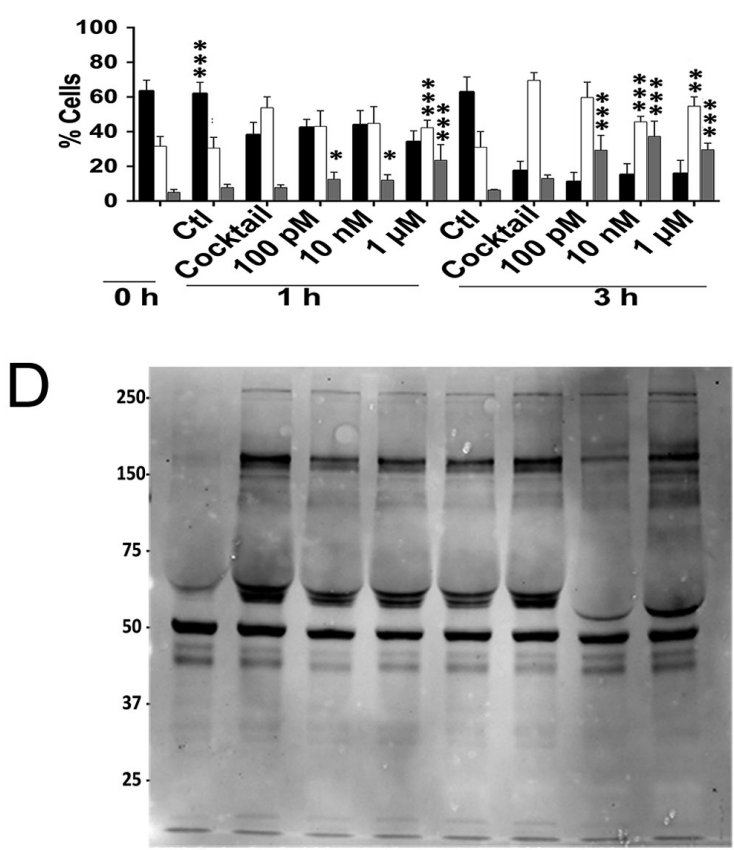

Ctl $3 \mathrm{~h}$ Cocktail $100 \mathrm{pM} 10 \mathrm{nM} 1 \mu \mathrm{M} 100 \mathrm{pM} 10 \mathrm{nM} 1 \mu \mathrm{M}$

Progesterone

17- $\beta$ estradiol

F

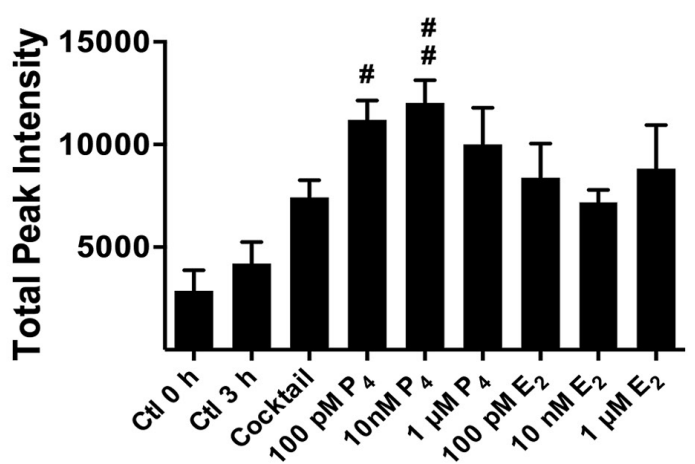

Figure 5 Effect of incubation with different progesterone and $17 \beta$-estradiol doses on the capacitation state of ram spermatozoa. Assessment of the capacitation status (CTC staining) of ram spermatozoa of control samples at $0 \mathrm{~h}$, and after $1 \mathrm{~h}$ and $3 \mathrm{~h}$ of incubation at $39{ }^{\circ} \mathrm{C}$ and $5 \% \mathrm{CO}_{2}$ with different progesterone and $17 \beta$-estradiol doses in TALP medium (A) and in the cocktail medium (B). Significant differences related to

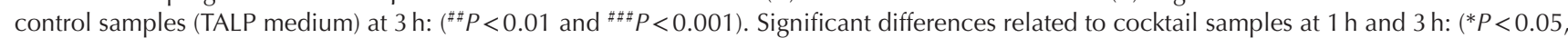
${ }^{* *} P<0.01$ and $\left.{ }^{* * *} P<0.001\right)$. Mean values \pm S.E.M. $(n=4)$. Protein tyrosine phosphorylation during in vitro capacitation analysed by Western blotting and quantified by densitometry: ( $\mathrm{C}$ and $\mathrm{E}$ ) control samples (TALP medium); ( $\mathrm{D}$ and F) cocktail samples. Significant differences related to control samples at $3 \mathrm{~h}$ of the incubation: $\left({ }^{\sharp} P<0.05\right.$ and $\left.{ }^{\sharp} P<0.01\right)$. Mean values \pm S.E.M. $(n=4)$. 
might be either different isoforms or two different types of a specific ovine sperm plasma membrane PR. Our chosen anti-PR antibody was an affinity-purified rabbit polyclonal antibody raised against a peptide mapping at the C-terminus of PR of human origin, where the steroid-binding site is located. We may presume that this important domain may be highly conserved between the putative membrane and nuclear receptors, as has been hypothesized by other authors (Luconi et al. 2004), and probably between different species as well. Indeed, the antibody used here has also been recommended for the detection of PR in different species, not only mammalian such as equine, canine, bovine and porcine, but also avian. However, our findings do not allow us to confirm the existence of the classical nuclear PR in ram spermatozoa, as already described in human (De Amicis et al. 2011) or porcine (De Amicis et al. 2012) spermatozoa. Conversely, we have demonstrated the existence of the two types of classical nuclear estrogen receptors (ER $\alpha$ and $E R \beta$ ) in ram spermatozoa. A band of about $66 \mathrm{kDa}$ and another of $55 \mathrm{kDa}$ were evidenced when anti-ER $\alpha$ and anti-ER $\beta$ antibodies were used, respectively, which were coincident with those described for conventional ER $\alpha$ and ER $\beta$ found in human spermatozoa (Aquila et al. 2004) and in other cell types (Mauro et al. 2014, Rizza et al. 2014). The signal of the band corresponding to ER $\beta$ was much more intense than that matching with $\mathrm{ER} \alpha$, in comparison with their respective positive controls. This is in concordance with results of other authors who have reported that ER $\beta$ is the most highly expressed isoform in spermatozoa (Aquila et al. 2004). With the antibodies used in this study, directed against a region of $\mathrm{N}$-terminus corresponding to amino acids 2-185 of ER $\alpha$ and 1-150 of ER $\beta$ of human origin, we did not detect any other putative ER. However, we cannot ignore the possible existence of specific estrogen-binding proteins on the sperm surface as revealed by other authors using antibodies directed against the steroid-binding domain of the classical ER (Luconi et al. 1999). It is worth highlighting that this is the first time that steroid hormone receptors have been described and localized in ram spermatozoa.

Progesterone and $17 \beta$-estradiol are able to exert rapid, non-genomic effects on spermatozoa and probably play an important role in vivo regulating several sperm functions involved in the fertilization process (reviewed in Bishop and Stormshak 2008 and Baldi et al. 2009). One necessary requisite to reach the oocyte is the sperm's ability to move properly through the female genital tract. In this regard, a positive effect of progesterone on the progressive motility of human spermatozoa has been shown (Contreras \& Llanos 2001), although this effect was not confirmed by other authors (Wang et al. 2001). Studies about the effects of estradiol on motility are scarce and apparently contradictory. While some authors have reported that this hormone induces sperm motility (Guido et al. 2011), others have showed that it decreases significantly the percentage of spermatozoa with progressive motility (Gautier et al. 2016). On the basis of our results, neither progesterone nor $17 \beta$-estradiol seemed to exert any influence on motility when ram spermatozoa were incubated in TALP medium. Likewise, we did not observe any effect on membrane sperm integrity, in contrast to previous results obtained with pig spermatozoa (De Amicis et al. 2012). Most descriptions of the actions of steroid hormones on spermatozoa are related to capacitation and the acrosome reaction. In the present study, we could not observe any significant change in the percentage of spermatozoa displaying a capacitated pattern in samples incubated with progesterone in a TALP medium, which is a commonly used medium to induce capacitation in most species. Due to the special difficulty to induce in vitro capacitation in ram spermatozoa (Grasa et al. 2006, Colas et al. 2008), we repeated the experiments adding a cocktail of compounds that maintains high intracellular cAMP levels, already successfully demonstrated for capacitating ram spermatozoa after three hours of incubation (Grasa et al. 2006, Colas et al. 2008). We found that the presence of $P 4$ resulted in a significant decrease in capacitated spermatozoa, concomitant with an increase in both the AR cells and protein tyrosine phosphorylation. Likewise, $100 \mathrm{pM}$ P4 also led to a significant decrease in TM sperm. Although several reports suggest a positive effect of progesterone on the capacitation of human spermatozoa (reviewed in Baldi et al. 2009), such results were obtained with very high hormone concentrations, much higher than those supposed to be in the site of capacitation, before the spermatozoa reached the oocyte. However, there are no doubts about the role of P4 in the induction of the acrosome reaction in most species, as demonstrated in human (Osman et al. 1989), mouse (Roldan et al. 1994), pig (Melendrez et al. 1994), stallion (Meyers et al. 1995) and goat (Somanath et al. 2000). In this study, we show for the first time, to the best of our knowledge, the influence of $\mathrm{P} 4$ on the ram sperm acrosome reaction. The fact that changes in the chlortetracycline staining patterns were not accompanied by a decrease in membrane integrity could suggest that P4 would bring ram spermatozoa to an end-point situation, ready to react in response to physiological stimuli such as the zona pellucida signals. This could be defined as a priming effect as described by other authors (Roldan et al. 1994, Sumigama et al. 2015). Conflicting results have been reported concerning the effects of $17 \beta$-estradiol on capacitation and the acrosome reaction. While some authors have described a direct stimulatory action (Adeoya-Osiguwa et al. 2003, Ded et al. 2013), others have reported a role in the modulation of the progesterone effects (Vigil et al. 2008, Sebkova et al. 2012). Our results have demonstrated the ability of $17 \beta$-estradiol to induce changes associated to the acrosome reaction by itself, especially when ram spermatozoa are incubated in a medium that increases 
the intracellular cAMP level. Furthermore, $100 \mathrm{pM}$ E2 resulted in a significant decrease in TM sperm, according to the results showed in equine (Gautier et al. 2016) and human (Guido et al. 2011) spermatozoa with $\mathrm{E} 2$ at $\mu \mathrm{M}$ concentrations. These results could point to different effects of E2 on sperm motility depending on concentration in a species-specific manner. The increase in the percentage of AR spermatozoa obtained with E2 was lower than that induced by P4 and did not trigger any modification in the phosphotyrosine pattern. This difference of results between both capacitation markers, i.e. CTC pattern and protein P-tyrosine rate evaluation could be explained on the basis that capacitation is a sequential process and several phenomena are concomitant with the beginning of the acrosome reaction (Baldi et al. 2000, Guraya 2000). It is widely considered that CTC staining is able to reflect the sperm capacitation state, although the molecular basis of CTC staining has not been fully understood yet (Rathi et al. 2001). Furthermore, changes in the content and localization of proteins phosphorylated at tyrosine residues (apart from others at serine and threonine) during in vitro capacitation have been shown and could be detected by Western blotting (Visconti et al. 1995). Both assays are considered as capacitation markers but events that induce these changes do not have to be simultaneous, but they might likely bring about in different moments of the capacitation process, and some molecules may trigger one of the events while not the another.

Numerous steroid hormones have been found to rapidly influence the ion channel activity in several cellular types (review in Nemere et al. 2003). In human sperm, progesterone activates the principal $\mathrm{Ca}^{2+}$ channel, CatSper (Lishko et al. 2011). CatSper-mediated $\mathrm{Ca}^{2+}$ influx leads to $\mathrm{Ca}^{2+}$ elevation in the sperm head (Xia et al. 2007), and thus, it could contribute to the $\mathrm{Ca}^{2+}$-dependent acrosome reaction. We could speculate that binding of progesterone to its specific receptors in sperm might activate CatSper via a signalling cascade and result in the acrosome reaction. 17 $\beta$-estradiol could also influence an ion channel since it induces a rapid and sustained increase in the intracellular calcium concentration as well (Luconi et al. 1999), but nevertheless until now there is no evidence for a link between $17 \beta$-estradiol and CatSper.

In conclusion, our study demonstrates that ovine spermatozoa have progesterone and estrogen receptors and that the presence of $E R \beta$ on the sperm surface decreases after capacitation and almost disappears after the acrosome reaction. Both steroid hormones are related with the induction of the acrosome reaction in ram spermatozoa.

\section{Declaration of interest}

The authors declare that there is no conflict of interest that could be perceived as prejudicing the impartiality of the research reported.

\section{Funding}

This study was supported by Grants CICYT AGL 2014-57863-R and DGA 2016-A26. M González-Arto had a fellowship GV BFI-2010-229 and S Gimeno a predoctoral contract from MIMECO BES-2015-072034.

\section{Acknowledgements}

The authors thank ANGRA for supplying the sires and $S$ Morales for the collection of semen samples.

\section{References}

Adeoya-Osiguwa SA, Markoulaki S, Pocock V, Milligan SR \& Fraser LR 2003 17beta-Estradiol and environmental estrogens significantly affect mammalian sperm function. Human Reproduction 18 100-107. (doi:10.1093/humrep/deg037)

Aquila S, Sisci D, Gentile M, Middea E, Catalano S, Carpino A, Rago V \& Ando S 2004 Estrogen receptor (ER) alpha and ER beta are both expressed in human ejaculated spermatozoa: evidence of their direct interaction with phosphatidylinositol-3-OH kinase/Akt pathway. Journal of Clinical Endocrinology and Metabolism 89 1443-1451. (doi:10.1210/ jc.2003-031681)

Arkoun B, Gautier C, Delalande C, Barrier-Battut I, Guenon I, Goux D \& Bouraima-Lelong H 2014 Stallion spermatozoa: putative target of estrogens; presence of the estrogen receptors ESR1, ESR2 and identification of the estrogen-membrane receptor GPER. General and Comparative Endocrinology 200 35-43. (doi:10.1016/j.ygcen.2014.02.016)

Baldi E, Luconi M, Bonaccorsi L, Muratori M \& Forti G 2000 Intracellular events and signaling pathways involved in sperm acquisition of fertilizing capacity and acrosome reaction. Front Biosciences $\mathbf{5}$ E110-E123. (doi:10.2741/A572)

Baldi E, Luconi M, Muratori M, Marchiani S, Tamburrino L \& Forti G 2009 Nongenomic activation of spermatozoa by steroid hormones: facts and fictions. Molecular and Cellular Endocrinology 308 39-46. (doi:10.1016/j.mce.2009.02.006)

Beato M, Chavez S \& Truss M 1996 Transcriptional regulation by steroid hormones. Steroids 61 240-251. (doi:10.1016/0039-128X(96)00030-X)

Bishop CV \& Stormshak F 2008 Non-genomic actions of progesterone and estrogens in regulating reproductive events in domestic animals. Veterinary Journal 176 270-280. (doi:10.1016/j.tvjl.2007.05.014)

Carson RS, Findlay JK, Clarke IJ \& Burger HG 1981 Estradiol, testosterone, and androstenedione in ovine follicular fluid during growth and atresia of ovarian follicles. Biology of Reproduction 24 105-113. (doi:10.1095/ biolreprod24.1.105)

Castilla JA, Gil T, Molina J, Hortas ML, Rodriguez F, Torresmunoz J, Vergara F \& Herruzo AJ 1995 Undetectable expression of genomic progesterone-receptor in human spermatozoa. Human Reproduction 10 1757-1760. (doi:10.1093/oxfordjournals.humrep.a136169)

Cheng FP, Gadella BM, Voorhout WF, Fazeli A, Bevers MM \& Colenbrander B 1998 Progesterone-induced acrosome reaction in stallion spermatozoa is mediated by a plasma membrane progesterone receptor. Biology of Reproduction 59 733-742. (doi:10.1095/biolreprod59.4.733)

Cheng FP, Wu JT, Tsai PS, Chang CLT, Lee SL, Lee WM \& Fazeli A 2005 Effects of cryo-injury on progesterone receptor(s) of canine spermatozoa and its response to progesterone. Theriogenology 64 844-854. (doi:10.1016/j.theriogenology.2004.10.021)

Chian RC, Ao A, Clarke HJ, Tulandi T \& Tan SL 1999 Production of steroids from human cumulus cells treated with different concentrations of gonadotropins during culture in vitro. Fertility and Sterility 71 61-66. (doi:10.1016/S0015-0282(98)00416-6)

Colas C, James P, Howes L, Jones R, Cebrian-Perez JA \& Muino-Blanco T 2008 Cyclic-AMP initiates protein tyrosine phosphorylation independent of cholesterol efflux during ram sperm capacitation. Reproduction Fertility and Development 20 649-658. (doi:10.1071/RD08023)

Conneely OM, Kettelberger DM, Tsai MJ, Schrader WT \& O'Malley BW 1989 The chicken progesterone receptor $A$ and $B$ isoforms are products of an alternate translation initiation event. Journal of Biological Chemistry 264 14062-14064. 
Contreras HR \& Llanos MN 2001 Detection of progesterone receptors in human spermatozoa and their correlation with morphological and functional properties. International Journal of Andrology 24 246-252. (doi:10.1046/j.1365-2605.2001.00294.x)

De Amicis F, Guido C, Perrotta I, Avena P, Panza S, Ando S \& Aquila S 2011 Conventional progesterone receptors (PR) B and PRA are expressed in human spermatozoa and may be involved in the pathophysiology of varicocoele: a role for progesterone in metabolism. International Journal of Andrology 34 430-445. (doi:10.1111/j.1365-2605.2010.01111.x)

De Amicis F, Santoro M, Guido C, Sisci D, Bruno R, Carpino A \& Aquila S 2012 Progesterone through progesterone receptors affects survival and metabolism of pig sperm. Animal Reproduction Science 135 75-84. (doi:10.1016/j.anireprosci.2012.09.006)

de Lamirande E, Harakat A \& Gagnon C 1998 Human sperm capacitation induced by biological fluids and progesterone, but not by $\mathrm{NADH}$ or $\mathrm{NADPH}$, is associated with the production of superoxide anion. Journal of Andrology 19 215-225.

Ded L, Sebkova N, Cerna M, Elzeinova F, Dostalova P, Peknicova J \& Dvorakova-Hortova K 2013 In vivo exposure to 17beta-estradiol triggers premature sperm capacitation in cauda epididymis. Reproduction 145 255-263. (doi:10.1530/REP-12-0472)

Dressing GE, Goldberg JE, Charles NJ, Schwertfeger KL \& Lange CA 2011 Membrane progesterone receptor expression in mammalian tissues: a review of regulation and physiological implications. Steroids 76 11-17. (doi:10.1016/j.steroids.2010.09.006)

Frederick JL, Lobo RA, Francis MM, Sauer MV, Macaso TM \& Paulson RJ 1991 Preovulatory follicular-fluid steroid-levels in stimulated and unstimulated cycles triggered with human chorionic-gonadotropin. Fertility and Sterility 55 44-47. (doi:10.1016/S0015-0282(16)54056-4)

Fujinoki M 2010 Suppression of progesterone-enhanced hyperactivation in hamster spermatozoa by estrogen. Reproduction 140 453-464. (doi:10.1530/REP-10-0168)

Fujinoki M, Takei GL \& Kon H 2016 Non-genomic regulation and disruption of spermatozoal in vitro hyperactivation by oviductal hormones. Journal of Physiological Sciences 66 207-212. (doi:10.1007/s12576-0150419-y)

Garcia-Lopez N, Ollero M, Muiño-Blanco T \& Cebrian-Perez JA 1996 A dextran swim-up procedure for separation of highly motile and viable ram spermatozoa from seminal plasma. Theriogenology 46 141-151. (doi:10.1016/0093-691X(96)00149-5)

Gautier C, Barrier-Battut I, Guenon I, Goux D, Delalande C \& BouraimaLelong H 2016 Implication of the estrogen receptors GPER, ESR1, ESR2 in post-testicular maturations of equine spermatozoa. General and Comparative Endocrinology 233 100-108. (doi:10.1016/j. ygcen.2016.05.022)

Gillan L, Evans G \& Maxwell WM 1997 Capacitation status and fertility of fresh and frozen-thawed ram spermatozoa. Reproduction Fertility and Development 9 481-487. (doi:10.1071/R96046)

Gomez MC, Catt JW, Gillan L, Evans G \& Maxwell WMC 1997 Effect of culture, incubation and acrosome reaction of fresh and frozenthawed ram spermatozoa for in vitro fertilization and intracytoplasmic sperm injection. Reproduction Fertility and Development 9 665-673. (doi:10.1071/R96122)

Grasa P, Cebrián-Perez JA \& Muiño-Blanco T 2006 Signal transduction mechanisms involved in in vitro ram sperm capacitation. Reproduction 132 721-732. (doi:10.1530/rep.1.00770)

Guido C, Perrotta I, Panza S, Middea E, Avena P, Santoro M, Marsico S, Imbrogno P, Ando S \& Aquila S 2011 Human sperm physiology: estrogen receptor alpha (ERalpha) and estrogen receptor beta (ERbeta) influence sperm metabolism and may be involved in the pathophysiology of varicocele-associated male infertility. Journal of Cellular Physiology 226 3403-3412. (doi:10.1002/jcp.22703)

Guidobaldi HA, Teves ME, Unates DR, Anastasia A \& Giojalas LC 2008 Progesterone from the cumulus cells is the sperm chemoattractant secreted by the rabbit oocyte cumulus complex. PLOS ONE 3 e3040. (doi:10.1371/journal.pone.0003040)

Guraya SS 2000 Cellular and molecular biology of capacitation and acrosome reaction in spermatozoa. International Review of Cytology 199 1-64. (doi:10.1016/s0074-7696(00)99001-6)

Harrison RA \& Vickers SE 1990 Use of fluorescent probes to assess membrane integrity in mammalian spermatozoa. Journal of Reproduction and Fertility 88 343-352. (doi:10.1530/jrf.0.0880343)
Jaiswal BS, Tur-Kaspa I, Dor J, Mashiach S \& Eisenbach M 1999 Human sperm chemotaxis: is progesterone a chemoattractant? Biology of Reproduction 60 1314-1319. (doi:10.1095/biolreprod60.6.1314)

Kastner P, Krust A, Turcotte B, Stropp U, Tora L, Gronemeyer H \& Chambon P 1990 Two distinct estrogen-regulated promoters generate transcripts encoding the two functionally different human progesterone receptor forms A and B. EMBO Journal 9 1603-1614.

Kay VJ, Coutts JR \& Robertson L 1994 Effects of pentoxifylline and progesterone on human sperm capacitation and acrosome reaction. Human Reproduction 9 2318-2323. (doi:10.1093/oxfordjournals. humrep.a138445)

Lishko PV, Botchkina IL \& Kirichok Y 2011 Progesterone activates the principal Ca2+ channel of human sperm. Nature 471 387-391. (doi:10.1038/nature09767)

Luconi M, Bonaccorsi L, Maggi N, Pecchioli P, Krausz C, Forti G \& Baldi E 1998 Identification and characterization of functional nongenomic progesterone receptors on human sperm membrane. Journal of Clinical Endocrinology and Metabolism 83 877-885. (doi:10.1210/ jc.83.3.877)

Luconi M, Muratori M, Forti G \& Baldi E 1999 Identification and characterization of a novel functional estrogen receptor on human sperm membrane that interferes with progesterone effects. Journal of Clinical Endocrinology and Metabolism 84 1670-1678. (doi:10.1210/ jcem.84.5.5670)

Luconi A, Francavilla F, Porazzi I, Macerola B, Forti G \& Baldi E 2004 Human spermatozoa as a model for studying membrane receptors mediating rapid nongenomic effects of progesterone and estrogens. Steroids 69 553-559. (doi:10.1016/j.steroids.2004.05.013)

Mauro L, Pellegrino M, De Amicis F, Ricchio E, Giordano F, Rizza P, Catalano S, Bonofiglio D, Sisci D, Panno ML et al. 2014 Evidences that estrogen receptor alpha interferes with adiponectin effects on breast cancer cell growth. Cell Cycle 13 553-564. (doi:10.4161/ cc.27455)

Melendrez CS, Meizel S \& Berger T 1994 Comparison of the ability of progesterone and heat solubilized porcine zona pellucida to initiate the porcine sperm acrosome reaction in vitro. Molecular Reproduction and Development 39 433-438. (doi:10.1002/mrd.1080390412)

Meyers SA, Overstreet JW, Liu IK \& Drobnis EZ 1995 Capacitation in vitro of stallion spermatozoa: comparison of progesterone-induced acrosome reactions in fertile and subfertile males. Journal of Andrology 16 47-54.

Nemere I, Pietras RJ \& Blackmore PF 2003 Membrane receptors for steroid hormones: signal transduction and physiological significance. Journal of Cellular Biochemistry 88 438-445. (doi:10.1002/jcb.10409)

Ollero M, Muino-Blanco T, Lopez-Perez MJ \& Cebrian-Perez JA 1996 Viability of ram spermatozoa in relation to the abstinence period and successive ejaculations. International Journal of Andrology 19 287-292. (doi:10.1111/j.1365-2605.1996.tb00477.x)

Oren-Benaroya R, Orvieto R, Gakamsky A, Pinchasov M \& Eisenbach M 2008 The sperm chemoattractant secreted from human cumulus cells is progesterone. Human Reproduction 23 2339-2345. (doi:10.1093/ humrep/den265)

Osman RA, Andria ML, Jones AD \& Meizel S 1989 Steroid induced exocytosis: the human sperm acrosome reaction. Biochemical and Biophysical Research Communications 160 828-833. (doi:10.1016/ 0006-291X(89)92508-4)

Parrish J, Susko-Parrish J, Winer MA \& First NL 1988 Capacitation of bovine sperm by heparin. Biology of Reproduction 38 1171-1180. (doi:10.1095/biolreprod38.5.1171)

Rago V, Aquila S, Panza R \& Carpino A 2007 Cytochrome P450arom, androgen and estrogen receptors in pig sperm. Reproductive Biology and Endocrinology 5 23. (doi:10.1186/1477-7827-5-23)

Rago V, Giordano F, Brunelli E, Zito D, Aquila S \& Carpino A 2014 Identification of $\mathrm{G}$ protein-coupled estrogen receptor in human and pig spermatozoa. Journal of Anatomy 224 732-736. (doi:10.1111/ joa.12183)

Rathi R, Colenbrander B, Bevers MM \& Gadella BM 2001 Evaluation of in vitro capacitation of stallion spermatozoa. Biology of Reproduction 65 462-470. (doi:10.1095/biolreprod65.2.462)

Rizza P, Barone I, Zito D, Giordano F, Lanzino M, De Amicis F, Mauro L, Sisci D, Catalano S, Dahlman Wright K et al. 2014 Estrogen receptor beta as a novel target of androgen receptor action in breast cancer cell lines. Breast Cancer Research 16 R21. (doi:10.1186/bcr3619) 
Roldan ER, Murase T \& Shi QX 1994 Exocytosis in spermatozoa in response to progesterone and zona pellucida. Science 266 1578-1581. (doi:10.1126/science.7985030)

Sabeur K, Edwards DP \& Meizel S 1996 Human sperm plasma membrane progesterone receptor(s) and the acrosome reaction. Biology of Reproduction 54 993-1001. (doi:10.1095/biolreprod54.5.993)

Sebkova N, Cerna M, Ded L, Peknicova J \& Dvorakova-Hortova K 2012 The slower the better: how sperm capacitation and acrosome reaction is modified in the presence of estrogens. Reproduction 143 297-307. (doi:10.1530/REP-11-0326)

Sirivaidyapong S, Bevers MM \& Colenbrander B 1999 Acrosome reaction in dog sperm is induced by a membrane-localized progesterone receptor. Journal of Andrology 20 537-544.

Solakidi S, Psarra AM, Nikolaropoulos S \& Sekeris CE 2005 Estrogen receptors alpha and beta (ERalpha and ERbeta) and androgen receptor $(A R)$ in human sperm: localization of ERbeta and AR in mitochondria of the midpiece. Human Reproduction 20 3481-3487. (doi:10.1093/ humrep/dei267)

Somanath PR \& Gandhi KK 2002 Expression of membrane associated non-genomic progesterone receptor(s) in caprine spermatozoa. Animal Reproduction Science 74 195-205. (doi:10.1016/S03784320(02)00168-9)

Somanath PR, Suraj K \& Gandhi KK 2000 Caprine sperm acrosome reaction: promotion by progesterone and homologous zona pellucida. Small Ruminant Research 37 279-286. (doi:10.1016/S09214488(99)00148-0)

Sumigama S, Mansellx S, Miller M, Lishko PV, Cherr GN, Meyers SA \& Tollner T 2015 Progesterone accelerates the completion of sperm capacitation and activates CatSper channel in spermatozoa from the Rhesus Macaque. Biology of Reproduction 93 130. (doi:10.1095/ biolreprod.115.129783)

Teves ME, Barbano F, Guidobaldi HA, Sanchez R, Miska W \& Giojalas LC 2006 Progesterone at the picomolar range is a chemoattractant for mammalian spermatozoa. Fertility and Sterility 86 745-749. (doi:10.1016/j.fertnstert.2006.02.080)

Uhler ML, Leung A, Chan SY \& Wang C 1992 Direct effects of progesterone and antiprogesterone on human sperm hyperactivated motility and acrosome reaction. Fertility and Sterility 58 1191-1198. (doi:10.1016/ S0015-0282(16)55568-X)

Vanderhyden BC \& Tonary AM 1995 Differential regulation of progesterone and estradiol production by mouse cumulus and mural granulosa cells by A factor(s) secreted by the oocyte. Biology of Reproduction $\mathbf{5 3}$ 1243-1250. (doi:10.1095/biolreprod53.6.1243)
Varas SM \& Jahn GA 2005 The expression of estrogen, prolactin, and progesterone receptors in mammary gland and liver of female rats during pregnancy and early postpartum: regulation by thyroid hormones. Endocrine Research 31 357-370. (doi:10.1080/07435800500454528)

Vigil P, Toro A \& Godoy A 2008 Physiological action of oestradiol on the acrosome reaction in human spermatozoa. Andrologia 40 146-151. (doi:10.1111/j.1439-0272.2007.00814.x)

Visconti PE, Bailey JL, Moore GD, Pan DY, Oldsclarke P \& Kopf GS 1995 Capacitation of mouse spermatozoa.1. Correlation between the capacitation state and protein-tyrosine phosphorylation. Development 121 1129-1137.

Wang Y, Storeng R, Dale PO, Abyholm T \& Tanbo T 2001 Effects of follicular fluid and steroid hormones on chemotaxis and motility of human spermatozoa in vitro. Gynecological Endocrinology 15 286-292. (doi:10.1080/gye.15.4.286.292)

Ward CR \& BT Storey 1984 Determination of the time course of capacitation in mouse spermatozoa using a chlortetracycline fluorescence assay. Developmental Biology 104 287-296. (doi:10.1016/00121606(84)90084-8)

Wu JT, Chiang KC \& Cheng FP 2006 Expression of progesterone receptor(s) during capacitation and incidence of acrosome reaction induced by progesterone and zona proteins in boar spermatozoa. Animal Reproduction Science 93 34-45. (doi:10.1016/j. anireprosci.2005.06.007)

Xia J, Reigada D, Mitchell CH \& Ren D 2007 CATSPER channel-mediated $\mathrm{Ca} 2+$ entry into mouse sperm triggers a tail-to-head propagation. Biology of Reproduction 77 551-559. (doi:10.1095/biolreprod.107.061358)

Xu JW, Gong J, Chang XM, Luo JY, Dong L, Jia A \& Xu GP 2004 Effects of estradiol on liver estrogen receptor-alpha and its mRNA expression in hepatic fibrosis in rats. World Journal of Gastroenterology 10 250-254.

Yamano S, Yamazaki J, Irahara M, Tokumura A, Nakagawa K \& Saito H 2004 Human spermatozoa capacitated with progesterone or a long incubation show accelerated internalization by an alkyl ether lysophospholipid. Fertility and Sterility 81 605-610. (doi:10.1016/j.fertnstert.2003.07.036)

Received 23 March 2017

First decision 13 April 2017

Revised manuscript received 30 June 2017

Accepted 14 July 2017 